PREPARED FOR THE U.S. DEPARTMENT OF ENERGY, UNDER CONTRACT DE-AC02-76CH03073

PPPL-4009

PPPL-4009

UC-70

\title{
Structural Analysis of the NCSX Vacuum Vessel
}

by

Fred Dahlgren, Art Brooks, Paul Goranson,

Mike Cole, and Peter Titus

September 2004

N/W|

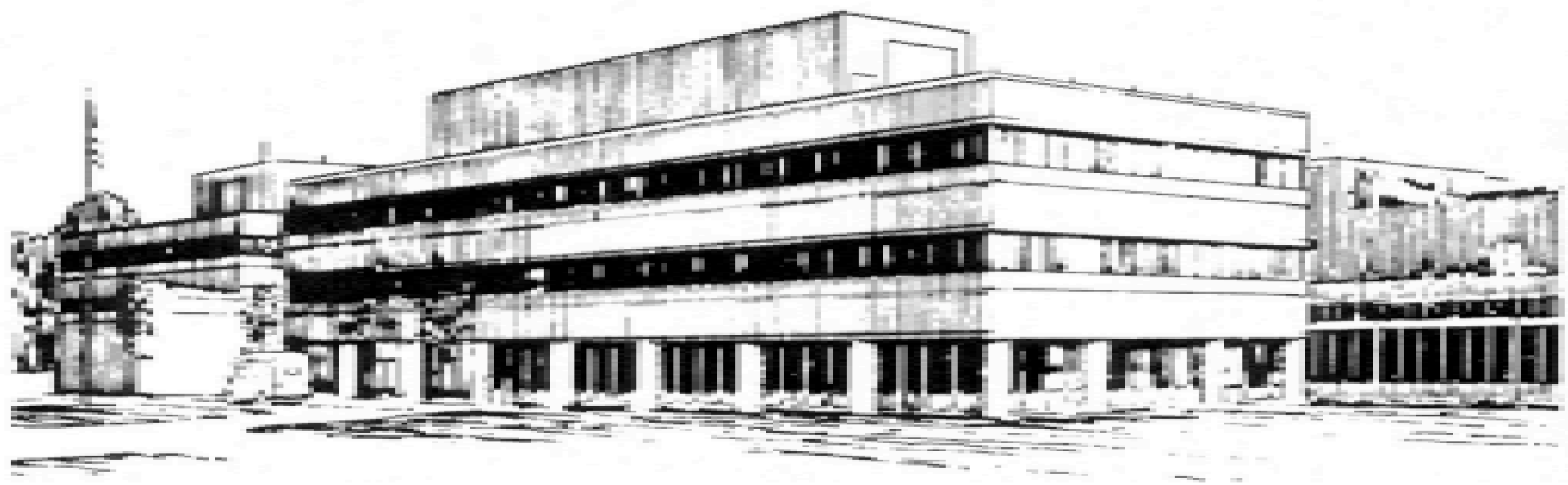

PRINCETON PLASMA PHYSICS LABORATORY PRINCETON UNIVERSITY, PRINCETON, NEW JERSEY 


\section{PPPL Reports Disclaimer}

This report was prepared as an account of work sponsored by an agency of the United States Government. Neither the United States Government nor any agency thereof, nor any of their employees, makes any warranty, express or implied, or assumes any legal liability or responsibility for the accuracy, completeness, or usefulness of any information, apparatus, product, or process disclosed, or represents that its use would not infringe privately owned rights. Reference herein to any specific commercial product, process, or service by trade name, trademark, manufacturer, or otherwise, does not necessarily constitute or imply its endorsement, recommendation, or favoring by the United States Government or any agency thereof. The views and opinions of authors expressed herein do not necessarily state or reflect those of the United States Government or any agency thereof.

\section{Availability}

This report is posted on the U.S. Department of Energy's Princeton Plasma Physics Laboratory Publications and Reports web site in Fiscal Year 2004. The home page for PPPL Reports and Publications is: http://www.pppl.gov/pub_report/

DOE and DOE Contractors can obtain copies of this report from:

U.S. Department of Energy

Office of Scientific and Technical Information

DOE Technical Information Services (DTIS)

P.O. Box 62

Oak Ridge, TN 37831

Telephone: (865) 576-8401

Fax: (865) 576-5728

Email: reports@adonis.osti.gov

This report is available to the general public from:

National Technical Information Service

U.S. Department of Commerce

5285 Port Royal Road

Springfield, VA 22161

Telephone: $1-800-553-6847$ or

(703) $605-6000$

Fax: (703) 321-8547

Internet: http://www.ntis.gov/ordering.htm 


\title{
Structural Analysis of the NCSX Vacuum Vessel
}

\author{
Fred Dahlgren, Art Brooks, PPPL, PO Box 451, Princeton NJ,08543
}

Paul Goranson, Mike Cole, ORNL, PO Box 2008 MS6169, Oak Ridge TN 37831-6169

Peter Titus, MIT Plasma Science and Fusion Center, 185 Albany Street Cambridge Ma. 02139

\begin{abstract}
The NCSX vacuum vessel has a rather unique shape being very closely coupled topologically to the three-fold stellerator symmetry of the plasma it contains. This shape does not permit the use of the common forms of pressure vessel analysis and necessitates the reliance on finite element analysis. The current paper describes the NCSX vacuum vessel stress analysis including external pressure, thermal, and electro-magnetic loading from internal plasma disruptions and bakeout temperatures of up to 400 degrees centigrade. Buckling and dynamic loading conditions are also considered.
\end{abstract}

\section{Introduction}

NCSX (National Compact Stellerator Experiment) is a DOE sponsored plasma physics experiment ${ }^{1}$ being built at PPPL (the Princeton University Plasma Physics Laboratory) in Princeton NJ. The primary goal of this experiment is to explore the behavior of magnetically confined plasmas in a compact stellerator geometry. The interest in this magnetic topology is based largely on the expected inherent stability of plasmas confined in this way.

The focus of this paper is to describe the analysis of the stresses, displacements, and structural stability of the vacuum vessel shell, ports, and structural support attachments in response to various anticipated loading conditions and to verify the adequacy of the current design for the NCSX experiment.

The main vessel shell is to be fabricated from 0.375 " thick Inconel-625 plate with port wall thicknesses varying from 0.125 " to 0.5 " depending on port diameter and configuration. The three 120 degree shells will be fabricated by welding together individually formed segments of Inconel plate and the three closure welds will be performed at final machine assembly.

Several anticipated loading conditions were investigated including external atmospheric pressure, gravity, thermal loads due to bakeout and normal operations, disruption eddy current loads, and seismic loading conditions.

\section{FEA Model Description:}

The vacuum vessel, modular coils (that produce the predominant magnetic fields), and the plasma, all have a closely coupled three-fold cylclic symmetry about the vertical axis of the machine. Figure 1. at the right shows the basic 120 degree single period FEA model of the vessel with cyclic-symmetric boundary conditions (multipoint constraints in Nastran). Below is a list of the model details and loading conditions investigated:
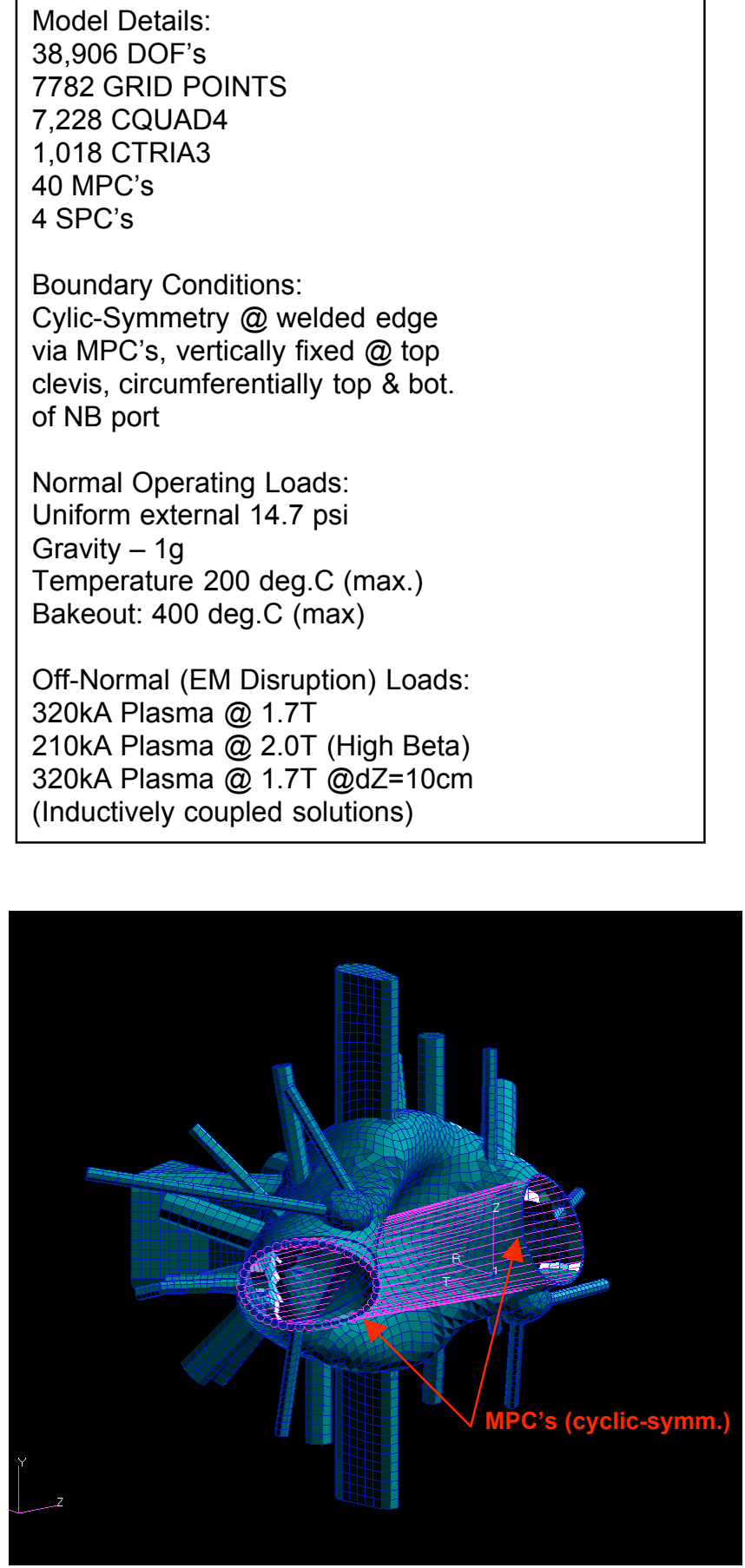

Figure 1. NCSX Vacuum Vessel FEA Model 
The FEA code used in these analysis was MSC/Nastran 2001-rev3 -Windows edition. The disruption loading was calculated using the PPPL code Spark ver.20b. Seismic and verification runs were made using Ansys Release 7.0.

Due to the very complex nature of the NCSX geometry it was necessary to model the vessel and other device components using a CAD (Computer Aided Design) program which relied on input from mathematically defined and generated surfaces. The vessel and coil shapes were dictated by the magnetic surfaces required on the plasma boundary. Pro-E was used for the CAD modeling and the main vessel geometry and ports were exported via Iges files which could be read by MSC/Patran (the modeling frontend and post processor for Nastran). The FEA model itself was generated and meshed in Patran from these surfaces, and is comprised of triangular and quadrilateral shell elements (CQUAD4 \& CTRIA3) which include both bending and membrane stiffness.

\section{Loading Conditions:}

The main loads of consequence acting on the vessel are gravity, the external atmospheric load, thermal gradients during bakeout and normal operations, and Lorentz forces produced by electromagnetic interaction with the eddy currents induced during plasma disruptions. Three different disruption loading conditions were assumed, a stationary disruption of a 350kA plasma in a 1.7 Tesla field after being vertically displaced $10 \mathrm{~cm}$, a stationary disruption of a 210 $\mathrm{kA}$ plasma in a 2 Tesla field in it's nominal mid-plane position (a high-beta configuration), and a $350 \mathrm{kA}$ plasma current in it's nominal position in a 1.7 Tesla field.

The uniform external atmospheric load was applied to the shell elements as pressures (PLOAD4 in Nastran apportions pressure loads to the element grid points via the element shape functions). The disruption loads were applied directly to the grid points via $3 \mathrm{D}$ force vectors. Nastran calculates gravity vector forces on element grid points by using the appropriate product of density and proportional volume associated with each node and using the specified acceleration direction and magnitude. Thermal loads are applied by specifying grid point temperatures and the strain free default temperature.

Although Princeton NJ is in a relatively stable earthquake zone, accelerations due to seismic events were also considered and are reported on elsewhere in these proceedings. $^{2}$

\section{FEA Stress Results:}

Figure 2. is a contour plot of displacements due to a 1 atmosphere pressure loading condition (ie. during normal operation). The peak displacement is seen to be of 0.25 " at the upper and lower ends of port-2 (at the $1^{\text {st }}$ port flange). The deflection of ports 2 (and 9) are the result of a local inward displacement of the vessel shell in the flat area of the shell in the vicinity of these two ports as shown in Figure 3 (note the upper range of the contour levels in this plot has been limited to 0.125 " to accentuate the local displacement contours). Figure 4. shows the Tresca stress contours on the outer shell surface for atmospheric loading with the peak stress of $15.2 \mathrm{ksi}$ occurring in the areas of highest curvature near the top (and bottom) of the shell.

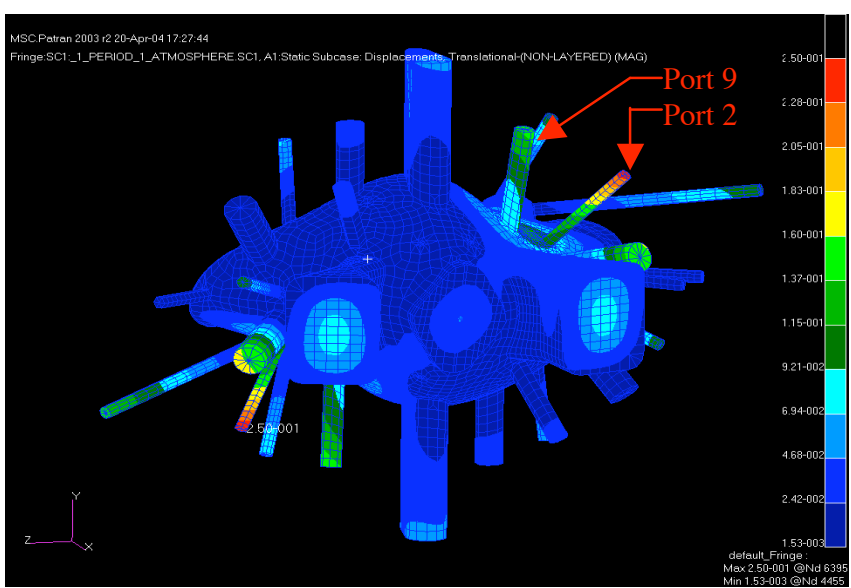

Figure 2. Displacements - Atmospheric Pressure Only

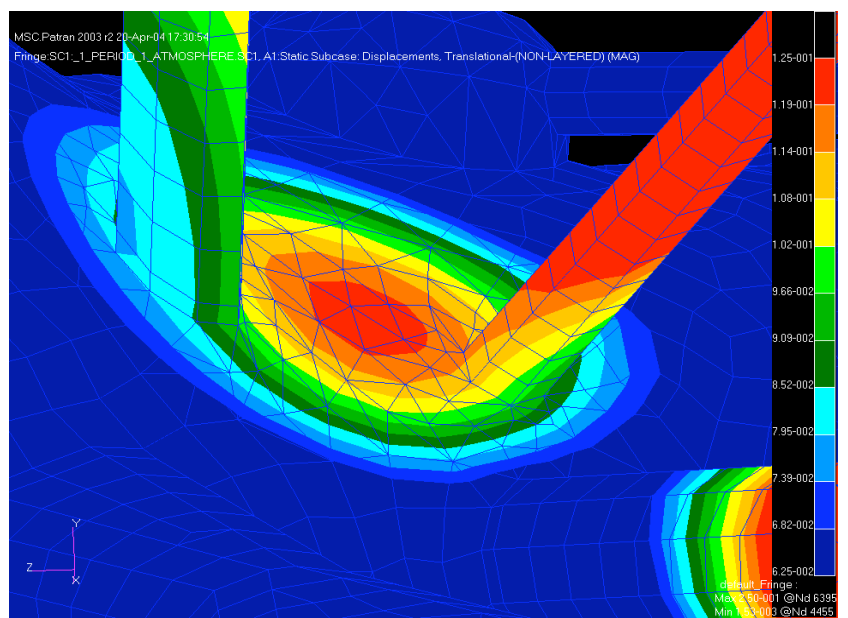

Figure 3. Displacements - Atmospheric Pressure Only

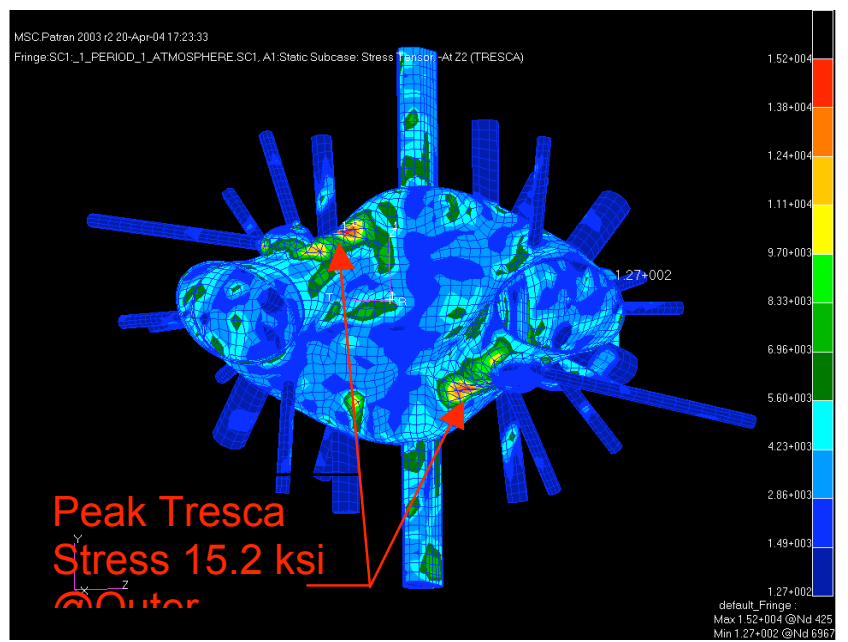

Figure 4. Tresca Stress - Atmospheric Pressure Only

The allowable stress intensity (Tresca stress) for $400{ }^{\circ} \mathrm{C}$ Inconel-625, per the ASME BPVC (Boiler \& Pressure 
Vessel Code), is $30.4 \mathrm{ksi}(209.6 \mathrm{MPa})$. These values are nominally based on the $1 / 3^{\text {rd }}$ minimum ultimate or $2 / 3^{\text {rd }}$ minimum yield stress specified for this material at temperature, and indicate a comfortable margin for normal operations.

Figure 5. is a vector plot of applied forces from a VDE (Vertical Disruption Event). The main eddy currents in the shell during plasma disruptions generally flow around the vessel mid-plane on the inner wall as can be seen by the concentration of forces there. Figure 6. is a contour plot of the Tresca stresses resulting from a combined loading condition which includes atmospheric, gravity, and the VDE EM disruption forces.

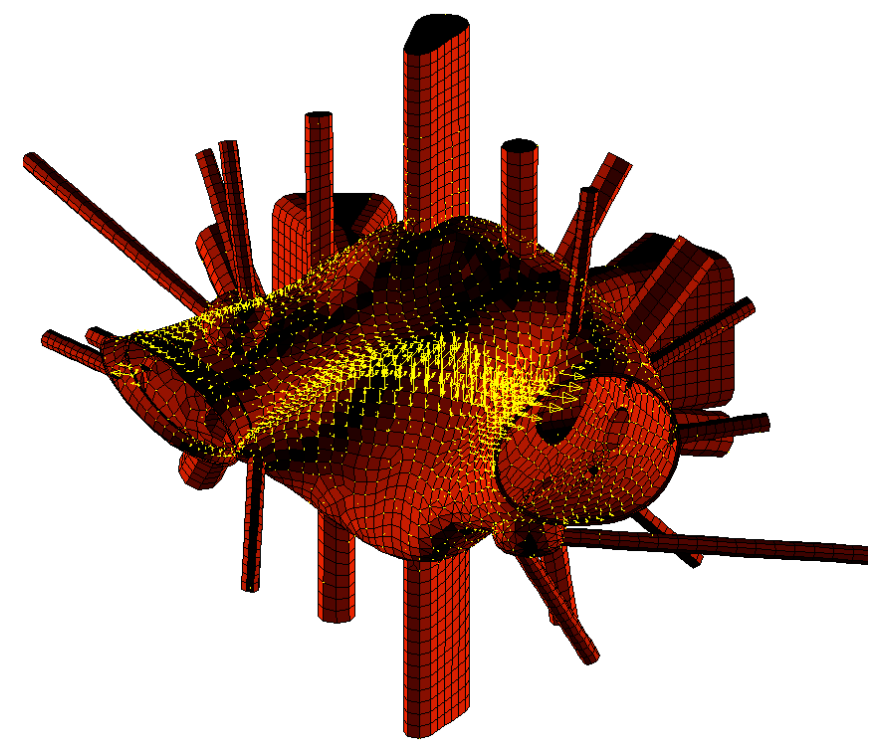

Figure 5. EM Self Forces on the Vessel Due to a VDE Disruption Loading.

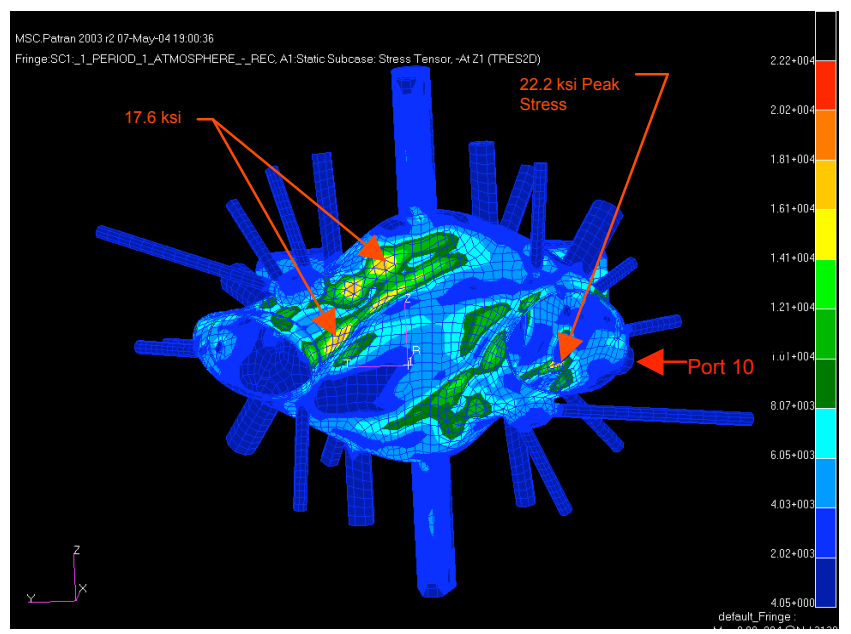

Figure 6. Tresca Stress Contours for a VDE + Atmosphere + Gravity Loading Condition.

The peak stress of $22.2 \mathrm{ksi}(153 \mathrm{MPa})$ is a localized stress and is seen to occur at the lower intersection of the Port 10 nozzle with the shell, with the stress in the high curvature region of the shell peaking at $17.7 \mathrm{ksi}(121.3 \mathrm{MPa})$.

Table I below summarizes the results for the various loading conditions investigated and compares those results to B.P.V.C. code allowable stress:

\begin{tabular}{|c|c|c|c|c|c|c|}
\hline & & TABLE & I Stres & s Resul & & \\
\hline Loading & $\begin{array}{c}\text { Peak } \\
\text { Stress } \\
\text { Intensi } \\
\text { ty ksi } \\
(\mathrm{MPa})\end{array}$ & \begin{tabular}{|l} 
Stress \\
Category \\
(per \\
ASME \\
BPVC)
\end{tabular} & \begin{tabular}{|l}
\multicolumn{1}{c|}{ Weld } \\
Efficiency \\
No Rad. \\
Insp.
\end{tabular} & $\begin{array}{c}\text { Allowable } \\
\text { Stress } \\
\text { (ksi) for } \\
\text { category }\end{array}$ & $\begin{array}{l}\text { Safety } \\
\text { Margin } \\
\text { (above } \\
\text { Allow.) }\end{array}$ & Notes \\
\hline Press. & $\begin{array}{c}16.1 \\
(111.0)\end{array}$ & $\begin{array}{c}\mathrm{PL}+ \\
\mathrm{Pb}\end{array}$ & $\begin{array}{l}0.7-> \\
23.0 \mathrm{ksi}\end{array}$ & $\begin{array}{c}1.5 \times \mathrm{Sm} \\
(50.1)\end{array}$ & 2.1 & @Turret \\
\hline $\begin{array}{c}\text { Press. + } \\
\text { Grav. }\end{array}$ & $\begin{array}{c}15.7 \\
(108.3)\end{array}$ & $\begin{array}{c}\mathrm{PL}+ \\
\mathrm{Pb}\end{array}$ & $\begin{array}{l}0.7-> \\
22.4 \mathrm{ksi}\end{array}$ & $\begin{array}{c}1.5 \times \mathrm{Sm} \\
(50.1)\end{array}$ & 2.1 & @Turret \\
\hline $\begin{array}{c}\text { Press. + } \\
\text { Grav. + } \\
\text { 500lb } \\
\text { Cant. }\end{array}$ & $\begin{array}{c}34.3 \\
(236.4)\end{array}$ & $\begin{array}{c}\mathrm{PL}+\mathrm{Pb} \\
+\mathrm{Q}\end{array}$ & $\begin{array}{l}0.5-> \\
68.6 \mathrm{ksi}\end{array}$ & $\begin{array}{c}3.0 \times \mathrm{Sm} \\
(100.2)\end{array}$ & 1.4 & $\begin{array}{l}\text { @ Turret } \\
\text { RF-1 } \\
\text { Administr } \\
\text { atively } \\
\text { controlled }\end{array}$ \\
\hline $\begin{array}{c}\text { Ohmic } \\
\text { Disrupt. } \\
\text { 320kA- } \\
1.7 \mathrm{~T}(+\mathrm{P}+\mathrm{G}) \\
\end{array}$ & $\begin{array}{c}17.7 \\
(122.0)\end{array}$ & $\begin{array}{c}\mathrm{PL}+ \\
\mathrm{Pb}\end{array}$ & 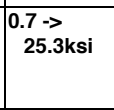 & $\begin{array}{c}1.5 \times \mathrm{Sm} \\
(50.1)\end{array}$ & 2.0 & $\begin{array}{l}\text { @Turret } \\
\text { DLF = 1.0 } \\
\text { (s/b less } \\
0.12)\end{array}$ \\
\hline $\begin{array}{c}\text { Hi-Beta } \\
\text { Disrupt. } \\
210 \mathrm{kA}- \\
2.0 \mathrm{~T}(+\mathrm{P}+\mathrm{G})\end{array}$ & $\begin{array}{c}16.1 \\
(111.0)\end{array}$ & $\begin{array}{c}\mathrm{PL}+ \\
\mathrm{Pb}\end{array}$ & $\begin{array}{l}0.7-> \\
23.0 \mathrm{ksi}\end{array}$ & $\begin{array}{c}1.5 \times \mathrm{Sm} \\
(50.1)\end{array}$ & 2.1 & $\begin{array}{l}\text { @ weld } \\
\text { flange } \\
\text { DLF = } 1.0 \\
(\mathrm{~s} / \mathrm{b} \text { less } \\
0.12)\end{array}$ \\
\hline $\begin{array}{c}\text { VDE } \\
\text { Disrupt. } \\
(+P+G) \\
320 k A-1.7 T- \\
10 \mathrm{~cm} \\
\end{array}$ & $\begin{array}{c}27.6 \\
(190.3)\end{array}$ & $\begin{array}{c}\mathrm{PL}+ \\
\mathrm{Pb}\end{array}$ & $\begin{array}{l}0.7-> \\
39.4 \mathrm{ksi}\end{array}$ & $\begin{array}{c}1.5 \times \mathrm{Sm} \\
(50.1)\end{array}$ & 1.2 & $\begin{array}{l}\text { @ weld } \\
\text { flange } \\
D L F=1.0 \\
(s / b \text { less } \\
0.12)\end{array}$ \\
\hline $\begin{array}{c}\text { Press. + } \\
\text { Grav. } \\
\text { +Thermal } \\
400 \mathrm{C}\end{array}$ & $\begin{array}{c}31.0 \\
(213.7)\end{array}$ & $\begin{array}{c}\mathrm{PL}+ \\
\mathrm{Pb}+\mathrm{Q}\end{array}$ & $\begin{array}{r}0.5-> \\
62.0\end{array}$ & $\begin{array}{c}3.0 \times \mathrm{Sm} \\
(100.2)\end{array}$ & 1.6 & $\begin{array}{l}\text { @NB-Port } \\
\text { Excessive } \\
\text { gradient } \\
\text { assumed }\end{array}$ \\
\hline
\end{tabular}

Appendix 4, Section VIII - Division 2 the general stress criteria and categories for vessel design based on stress analysis can be found in Table II below:

\begin{tabular}{|l|l|l|}
\hline \multicolumn{3}{|c|}{ TABLE II } \\
\hline Category & \multicolumn{1}{|c|}{ Description } & Not to exceed \\
\hline $\mathrm{Pm}$ & $\begin{array}{l}\text { Primary membrane Stress (Average across solid section, } \\
\text { produced only by body forces and mechanical loads). }\end{array}$ & $1.0 \mathrm{k} \times \mathrm{S}_{\mathrm{m}}$ \\
\hline $\mathrm{PL}$ & $\begin{array}{l}\text { Local Primary membrane Stress (Average stress across } \\
\text { section, includes discontinuities but not Stress } \\
\text { concentrations). }\end{array}$ & $1.5{\mathrm{k} \times \mathrm{S}_{\mathrm{m}}{ }^{*}}^{*}$ \\
\hline $\mathrm{Pb}$ & $\begin{array}{l}\text { Primary bending stress (Stresses proportional to the } \\
\text { distance from the centroid of a solid section - excludes } \\
\text { discontinuities \& str.conc.). }\end{array}$ & $1.5 \mathrm{k} \times \mathrm{S}_{\mathrm{m}}{ }^{*}$ \\
\hline $\mathrm{Q}$ & $\begin{array}{l}\text { Secondary Membrane + bending stresses, self } \\
\text { equilibrating, due to thermal or mechanical loads, or } \\
\text { discontinuities (excludes local stress concentrations). }\end{array}$ & $3.0 \mathrm{k} \times \mathrm{S}_{\mathrm{m}}{ }^{* *}$ \\
\hline $\mathrm{F}$ & $\begin{array}{l}\text { Incremental stress added by stress concentrations } \\
\text { (notch), thermal stresses producing thermal fatigue. }\end{array}$ & $\mathrm{NA}$ \\
\hline
\end{tabular}

Applying the Pressure vessel code criteria, which includes a knock down factor to the allowable stress intensity for weld efficiency, the minimum margin for all loading conditions considered, was 1.2 for the combined loading VDE case. Since disruption loads will be applied over a relatively short period ( $\sim 1$ to $30 \mathrm{msec}$.), the dynamic loading factor must be considered. In general if the applied load frequency is significantly different from natural frequency of the structure the DLF (Dynamic Load Factor) will be less than 1.0. To determine the natural frequency of the vessel, a modal analysis was run and the primary undamped natural 
period of 1.25 seconds, was found to be a rocking mode with the inner and outer portions of the shell moving vertically in opposite directions with the motion centered around the vertical supports. Based on the ratio of periods between the natural frequency of the vessel and VDE disruption loading, the DLF was determined to be $\sim 0.14$ indicating that only a small fraction of the dynamic load will actually produce a response in the vessel structure. Higher order modes might involve many of the cantilevered ports, but since the dynamic portion of the loading is almost exclusively in the shell, the VDE will have little or no effect on the ports.

\section{Structural Stability:}

To determine the structural stability of the vessel due to the external pressure and disruption loads, a buckling analysis was performed. In Nastran the common method of determining structural stability is to apply the loading conditions anticipated in normal service as a static loading condition and from that result calculate the differential stiffness matrix and then solve the resulting eigenvalue problem below:

$$
\left[\mathbf{K}+\square \mathbf{K}_{\mathbf{d}}\right]\{\mathbf{u}\}=\mathbf{0}
$$

The resulting (primary) eigenvalue is then the factor by which the applied load must be multiplied to produce buckling. If the original static load applied is one atmosphere the resulting eigenvalue is then the critical buckling load factor or safety factor.

For a single external atmospheric load (14.7 psi), the critical buckling load factor was found to be 12.99 indicating it would theoretically require approximately 191 psi external pressure to collapse the vessel (the resulting eigenvector seen in figure 7 shows the primary buckling mode shape). While 12.99 appears to be quite a large margin such results are typically viewed with some caution. The ASME-BPV code generally requires minimum safety factors of $5 \mathrm{x}$ or greater on critical buckling of externally loaded vessels due to the uncertainties in geometry, loading conditions, and material properties. Regularly shaped structures commonly used in autoclaves, like spheres, torrispherical heads and cylindrical shells, tend to be more sensitive to variations in thickness and deviations from their theoretical geometry and tend to buckle at loads significantly lower than normal stability theory might predict (hence the large safety factors of $5 \mathrm{x}$ or greater), however, due to the highly irregular shape of the NCSX vessel, it is less likely to be susceptible to premature buckling due to minor variations in thickness or geometry.

That said there are still other considerations that tend to produce lower buckling margins than this eigenvalue analysis predicts, and suggests these margins should only be used as an upper bound indicator of global structural stability. There are several assumptions inherent in the current method of buckling analysis, the principle one being that the entire structure at temperature and under load remains linearly elastic and therefore small deflection theory still applies (ie. the applied loads from which the differential stiffness is derived, maintain the same magnitude, direction, and point of application as the structure deflects).

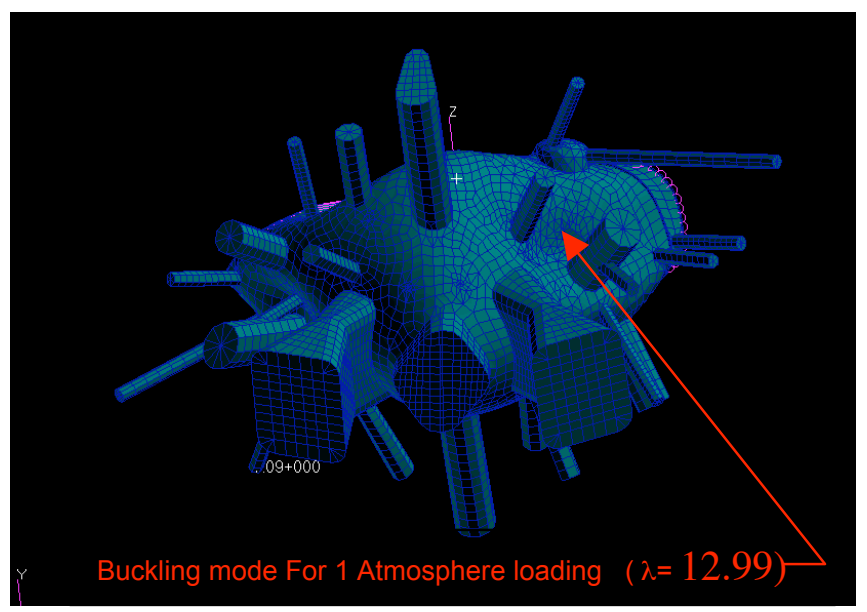

Figure 7. Primary Buckling Mode Shape

Figure 8 is a contour plot of Tresca stresses that exceed the yield stress of Inconel-625 at 400 deg.C ( $\sim 60 \mathrm{ksi})$ when a full 191 psi (12.99 x 14.7 psi) external load is applied. Clearly, these localized areas of high stress would have yielded, producing large shell displacements, long before a 191 psi pressure was reached, so the safety factor quoted above of 12.99 is not necessarily a true indicator of the margin for structural failure.

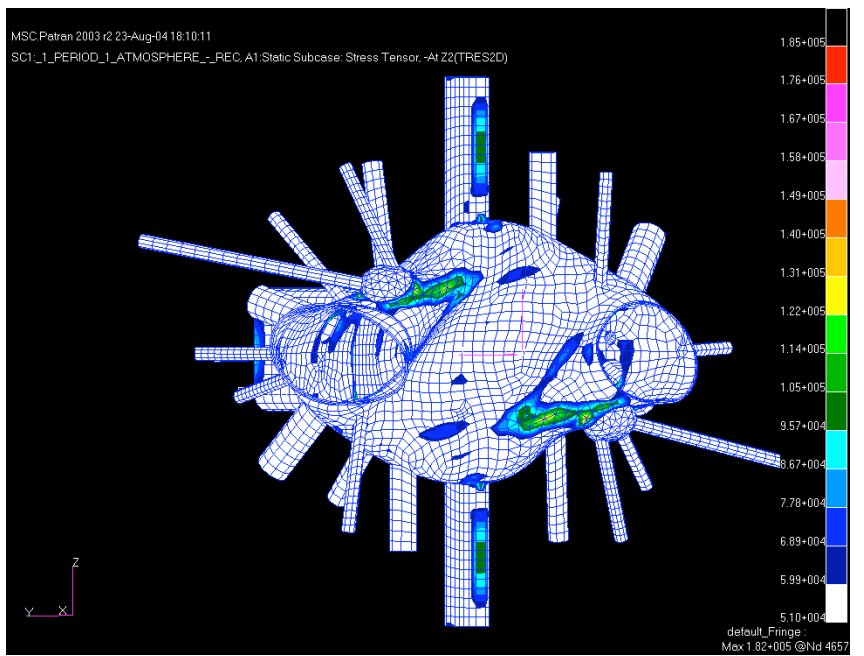

Figure 8. Stresses exceeding yield for 12.99 Bar Loading

Figure 9 is a Tresca stress contour plot for a $5 \mathrm{x}$ atmospheric (73.5 psi) loading condition. It can be seen that only a very small region of the shell at the corner intersection with the rectangular ports exceeds yield and it therefore can be concluded that only localized yielding and small displacements would occur under these loading conditions. The main conclusion that can be drawn from these results is that the buckling margin, at a minimum, exceeds $5 \mathrm{x}$ for atmospheric loading at the maximum bakeout temperature. 


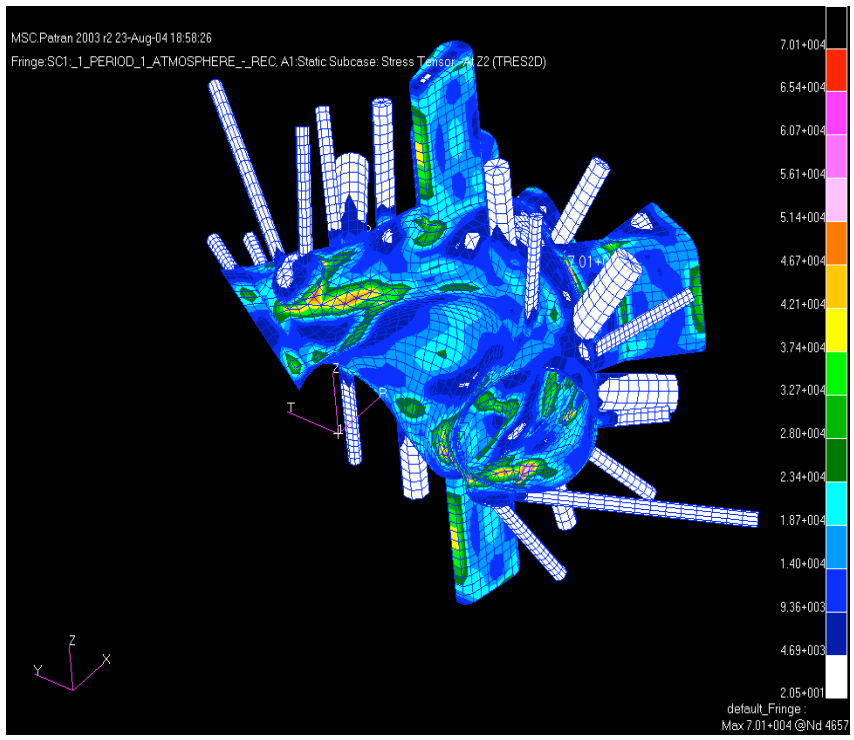

Figure 9. Stresses for 5 Bar Loading $\left(\mathrm{S}_{\text {Tresca }}<\mathrm{S}_{\text {yield }}\right)$

\section{Discussion and Conclusions:}

The purpose of this analysis was to determine the stresses, displacements, and structural stability of the vacuum vessel shell, ports, and structural support attachments in response to various loading conditions and to verify the adequacy of the current design. Several anticipated loading conditions were investigated including external atmospheric pressure, gravity, thermal loads due to bakeout and normal operations, disruption eddy current loads, and seismic loading conditions. The following are the main findings of this analysis:

-Stresses from the normal operating load runs (Atmospheric, Gravity, Thermal, $+250 \mathrm{lb}$ cantilevered load) in the shell and ports are generally well below the code allowable stress with the exception of the Port-18 \& 15 cantilevered loading condition. Recommend either:

a) thickening the turret wall and port nozzle to reduce stress at the nozzle/potersection and to reduce vertical deflections of the port,

b) Implement a radially compliant vertical nozzle support off the cryostat, or

c) Limit the cantilevered loading on Port-15 and the RF ports.

-Shell displacements for normal operations are generally low with the exception of the area between Port-2 \& Port-9 which indicate a displacement of 0.125 " total. This results in a .25 " deflection of these ports at the $1^{\text {st }}$ flange. These displacements may be reduced by thickening or reinforcing the shell locally to reduce these deflections if necessary.

-Dynamic loading from VDE (10 cm vertically displaced) plasma disruptions are the most severe but the peak (Main flange) stress intensities are below allowables for the full 1.0x DLF (Dynamic Load Factor). Where we assume the interior welds in the peak stress (flange) regions experience the same stresses, and using a weld efficiency of 0.7 , we have a margin of $20 \%$ on code allowables.

-Critical Buckling loads for the worst VDE disruption load (using DLF=1.0) and including atmospheric and gravity loading, the critical load factor was 12 . Due to the irregular shape of this vessel local buckling modes predominate, generally localized in the shell near ports 2 and 9. The current design has a buckling margin $>5$.

-Modal analysis indicates the undamped primary structural mode of $0.8 \mathrm{~Hz}$ with the vessel rocking on the vertical supports. Numerous low frequency modes are present in ports $15,2,9, \mathrm{rf}-1 \& \mathrm{rf}-2$. Several are in the frequency range of earthquake spectrum and are anticipated to participate in the horizontal and vertical accelerations of any seismic event. Since their mass is relatively low, and deflections of these ports are limited by the Cryostat penetrations, no significant permanent damage to the vessel or structure from a seismic event is anticipated although some dampening, perhaps from the cryostat boots and feed-thrus might be implemented with good effect here.

-Areas where local bending + membrane stress may exceed yield, and areas of discontinuity or stress concentration were evaluated for fatigue. The primary cyclic loading (apart from the low number of pump-down/bakeout cycles) will be disruption loads. Assuming a conservative estimate of 5 disruption loads per day, over 10 years of operation, the cumulative number of cycles will be $\sim 12,500$. The stress range will vary based on location and residual stress. Specialty Metals/Huntington Alloys data indicates a fatigue life well in excess of 100 million cycles at the maximum anticipated cyclic stress for the base metal. For weld filler material, the literature indicates high margins for the cycle life and stress range anticipated. After accounting for shakedown, all stress excursions will fall well within the elastic range for all loading conditions considered.

-The creep-rupture properties at the maximum bakeout temperature of $400 \mathrm{C}$ are extremely good for this material (Inconel 625) with rupture life in excess of 100,000 hrs (11.4 years) for the peak stress levels calculated. The accumulated vessel exposure to bakeout temperatures is not expected to exceed $10 \%$ of the rupture life $(10,000 \mathrm{hrs})$.

\section{ACKNOWLEDGMENTS}

This work supported under DOE contract DE-AC02$76 \mathrm{CH} 03073$

\section{REFERENCES}

[1] R Simmons, "Recent Progress in the Design, Fabrication, and R\&D of NCSX", These proceedings.

[2] P. Titus, M.Kalish "Seismic Analysis of The National Compact Stellarator Experiment (NCSX)", These Proceedings. 



\section{External Distribution}

Plasma Research Laboratory, Australian National University, Australia

Professor I.R. Jones, Flinders University, Australia

Professor João Canalle, Instituto de Fisica DEQ/IF - UERJ, Brazil

Mr. Gerson O. Ludwig, Instituto Nacional de Pesquisas, Brazil

Dr. P.H. Sakanaka, Instituto Fisica, Brazil

The Librarian, Culham Laboratory, England

Mrs. S.A. Hutchinson, JET Library, England

Professor M.N. Bussac, Ecole Polytechnique, France

Librarian, Max-Planck-Institut für Plasmaphysik, Germany

Jolan Moldvai, Reports Library, Hungarian Academy of Sciences, Central Research Institute for Physics, Hungary

Dr. P. Kaw, Institute for Plasma Research, India

Ms. P.J. Pathak, Librarian, Institute for Plasma Research, India

Ms. Clelia De Palo, Associazione EURATOM-ENEA, Italy

Dr. G. Grosso, Instituto di Fisica del Plasma, Italy

Librarian, Naka Fusion Research Establishment, JAERI, Japan

Library, Laboratory for Complex Energy Processes, Institute for Advanced Study, Kyoto University, Japan

Research Information Center, National Institute for Fusion Science, Japan

Dr. O. Mitarai, Kyushu Tokai University, Japan

Dr. Jiangang Li, Institute of Plasma Physics, Chinese Academy of Sciences, People's Republic of China

Professor Yuping Huo, School of Physical Science and Technology, People's Republic of China

Library, Academia Sinica, Institute of Plasma Physics, People's Republic of China

Librarian, Institute of Physics, Chinese Academy of Sciences, People's Republic of China

Dr. S. Mirnov, TRINITI, Troitsk, Russian Federation, Russia

Dr. V.S. Strelkov, Kurchatov Institute, Russian Federation, Russia

Professor Peter Lukac, Katedra Fyziky Plazmy MFF UK, Mlynska dolina F-2, Komenskeho Univerzita, SK-842 15 Bratislava, Slovakia

Dr. G.S. Lee, Korea Basic Science Institute, South Korea

Institute for Plasma Research, University of Maryland, USA

Librarian, Fusion Energy Division, Oak Ridge National Laboratory, USA

Librarian, Institute of Fusion Studies, University of Texas, USA

Librarian, Magnetic Fusion Program, Lawrence Livermore National Laboratory, USA

Library, General Atomics, USA

Plasma Physics Group, Fusion Energy Research Program, University of California at San Diego, USA

Plasma Physics Library, Columbia University, USA

Alkesh Punjabi, Center for Fusion Research and Training, Hampton University, USA

Dr. W.M. Stacey, Fusion Research Center, Georgia Institute of Technology, USA

Dr. John Willis, U.S. Department of Energy, Office of Fusion Energy Sciences, USA

Mr. Paul H. Wright, Indianapolis, Indiana, USA 
The Princeton Plasma Physics Laboratory is operated by Princeton University under contract with the U.S. Department of Energy.

\author{
Information Services \\ Princeton Plasma Physics Laboratory \\ P.O. Box 451 \\ Princeton, NJ 08543
}

Phone: 609-243-2750

Fax: 609-243-2751

e-mail: pppl_info@pppl.gov

Internet Address: http://www.pppl.gov 